\title{
Twenty Years after Beijing: Can Promises be Turned into Progress?
}

\author{
Jessica Woodroffe
}

\begin{abstract}
Twenty years since the landmark women's conference at Beijing, and as the post-2015 agenda is concluded, it is clear that there has been a significant increase in rhetoric from governments and even some notable achievements in the field of women's equality and rights. But a failure to tackle underlying causes - particularly the persistent unequal power relations between women and men - has thwarted real, sustainable progress. A report by the Gender and Development Network has identified four areas in need of far greater political focus and resources: working with marginalised women to build their own agency; supporting women's collective action; promoting positive social norms; and reassessing macroeconomic policies and the role of the care economy.
\end{abstract}

\section{Introduction}

In every country, women and girls face discrimination and human rights abuse solely because of their gender; they have less power, resources and voice than men and boys. The year 2015 provides an important moment to reflect on what has, and has not, been achieved on gender equality. It is 20 years since governments at the Fourth World Conference on Women agreed the landmark Beijing Declaration and Platform for Action (BPfA), and 15 years since the ground-breaking UN Security Council Resolution (UNSCR) 1325 recognised the importance of women's full and equal participation as actors for peace and security. Meanwhile, the conclusion of negotiations on the post-2015 framework and Sustainable Development Goals (SDGs) during summer 2015 provides an opportunity to look towards the future and garner renewed political will.

Given this coincidence of opportunities the Gender and Development Network decided to collaborate, for the first time, with two sister networks in an attempt to ensure that the lessons of the past influence the policymaking of the future. ${ }^{1}$ The Turning Promises into Progress report (GADN, GAPS and UK SRHR Network 2015) includes reflections on past decades, and recommendations for future action. Perhaps the most striking change witnessed over the last two decades has been the increased discourse around gender equality, with a proliferation of political rhetoric and international agreements. These range from the seven UN Security Council resolutions on Women, Peace and Security, to regional agreements including the Maputo Protocol on the rights of women in Africa, and the recent Council of Europe Convention on preventing and combating violence against women (the Istanbul Convention). The centrality of gender equality to achieving development was also recognised in 2000 when the Millennium Development Goals (MDGs) included a specific goal on gender equality and women's empowerment (MDG 3) while MDG 5 included targets on maternal mortality and reproductive health. The role of gender within the UN system was further elevated with the creation of the Entity for Gender Equality and the Empowerment of Women (UN Women) in 2011.

This increased attention on gender equality appears to have made it harder for political actors to openly oppose it - at least in international fora. Moreover, governments' obligation to track their progress against MDG 3 led to increased national commitments (occasionally matched with increased funding) (Smee and Woodroffe 2013). More issues are on the table too, most notably violence against women and girls (VAWG), the exclusion of which from the MDGs is now widely seen as an error (ibid.).

These commitments have sometimes led to hard won gains for women, particularly in areas such as education, high-level political participation and maternal health where the MDGs brought some new funding. For example, all regions have achieved, 
or are close to achieving, gender parity in primary education (UN 2014a: 20). The number of women dying in pregnancy and childbirth has almost halved since 1990, although from a very high starting point (UK SRHR Network et al. 2014). Women parliamentarians have also increased in number, although again from a low base (IPU 2014).

Compared to what needs to be done, however, success has been more limited. In every country in the world, women and girls continue to spend substantially longer than men and boys on unpaid care work (UN Women 2015). Women earn less than men for doing comparable jobs (ILO 2009), make up nearly two-thirds of the working poor, and are twice as likely as men to be living in extreme poverty (Women Deliver 2013). In 26 countries inheritance laws discriminate against women (Klugman et al. 2014). Women's voices are also still not heard: a review of 33 peace negotiations found that only 4 per cent of participants were women (UN Women 2012). One in three women worldwide have experienced either intimate partner and/or sexual violence (WHO 2013).

Across all seven issues explored in Turning Promises into Progress, progress has been slow and piecemeal (GADN et al. 2015). There are a number of reasons for this. In some cases interventions have been too narrowly focused; for example, efforts to increase women's political participation have concentrated too much at national rather than local levels, and perhaps more importantly have focused too much on numbers rather than actual influence. Despite the big push on girls' education over recent years, adult women's literacy has barely progressed at all and has attracted very little investment (Global Campaign for Education 2011: 11). Rates of literacy for women with disabilities are even lower (Groce and Bakshi 2011).

Resources continue to be scarce. In 2012, only 21 per cent of official development assistance (ODA) went to spending with an element on gender equality, of which only 3 per cent was allocated to projects with gender equality as a principal objective (Development Initiatives 2014). The resources available were also frequently not fit for purpose, failing to provide the long-term flexible funding for transformative change that was really needed, partly as a result of the privatisation of aid and partly due to the focus on short-term, results-driven donor assistance (Wallace and Porter 2013).

But probably most importantly, the underlying causes of gender equality have not been addressed. A focus on opportunities for individual girls and women has obscured the underlying power relations between genders that are fundamental to the way in which societies are organised. Still, 20 years after Beijing, women are sometimes referred to as a 'vulnerable group' in need of protection (see, for example, UN 2014b). This framing has allowed the status quo of discriminatory social norms and unjust social and economic structures to remain, with women still excluded from key decision-making processes. For example, much of the donor discourse on women's economic empowerment since Beijing has concentrated on raising the income of individual women through jobs or microcredit programmes. While useful, this response has been limited because it ignores the barriers women face, such as discriminatory social norms around occupational segregation and unpaid care roles (Kabeer 2005).

A re-framing of work on gender equality is needed that recognises women's and girls' rights, their role as agents of change, and the unequal power relations between women and men. Every woman and girl experiences discrimination differently, and many of the most marginalised face multiple discriminations such as on the basis of their income, sexuality, marital status, ethnic group or disability. But there are also shared realities, universal themes and common lessons that can be built upon.

\section{Gender equality: moving forward}

There is, of course, no magic bullet, and change is needed on multiple fronts. However, in Turning Promises into Progress four areas are identified as barriers to gender equality that particularly require action: (1) working with marginalised women to build their agency; (2) supporting women's collective action; (3) promoting positive social norms; and (4) reassessing macroeconomic policies and the role of the care economy.

\subsection{Building women's agency}

For women to realise their rights they need not only access to more resources and power, but also the ability to make and act on choices to take advantage of these opportunities and to identify their own priorities (Eyben 2011). For example, economic empowerment requires that women have control over the income they earn and can exercise choice over what work they do and how they spend their time (Kidder, Bright and Green 2014). While many organisations work with marginalised women to promote their rights, there is a vital role for organisations specifically led by women for women that have a primary focus on promoting women's rights and gender equality. These organisations are 
frequently well placed to work with marginalised women and girls to build their capacity and agency and speak for themselves, and are in need of far greater political, and appropriate financial, support (Arutyunova and Clark 2013).

\subsection{Women's collective action}

Women's organised collective action is critical for creating change. Research across five fragile and conflict-affected countries found women's rights organisations to have played a crucial role in mitigating conflict and building peace (ActionAid, IDS and Womankind Worldwide 2012). A study of measures to tackle VAWG across four decades found the mobilisation of women's organisations to be a critical factor (Htun and Weldon 2012). Meanwhile, one of the reasons given for a failure to translate economic growth into gender equality has been the absence of collective agency among women workers (Kabeer 2014). Recognising and supporting this collective action will be vital in the next decade.

\subsection{Promoting positive social norms}

Discriminatory social norms - widely shared beliefs, practices and rules - provide a veneer of acceptability or inevitability to gender inequality and are a major reason why more progress has not been made in the last two decades (Harper et al. 2014). By normalising women's and girls' roles, for example as 'carers' and followers rather than 'breadwinners' and leaders, they perpetuate unequal power relations between women and men, which are then further reproduced by institutions such as the police, military, education systems and the media. Such discriminatory social norms permeate every aspect of women's lives. Norms around 'women's work' justify low pay, limit organising, and reinforce occupational segregation (Kabeer 2014). Transgression of the dominant norms can lead to harsh sanctions. For example, in Afghanistan threats to the safety of female politicians still restrict their full participation in public life despite quotas on political representation (UN 2010). In response to explicit threats faced by women candidates, Bolivia passed a law against political VAWG in 2013 (Ministry of Communication, Bolivia 2012).

Donor recognition of the role of discriminatory social norms in undermining attempts at gender equality is relatively recent (see, for example,

Klugman et al. 2014). Fear of 'cultural imperialism' has been a hindrance, as has the claim that changes in social norms are not easily measured so cannot be used as an indicator. This latter assertion has now been refuted, with examples of how measurement can take place, and there are calls to include social norm change as indicators in the post-2015 framework (Harper et al. 2014). Such promotion of positive norms is possible but takes time, and requires investment in empowering women and girls to question these norms and go 'against the grain', while working with communities, particularly influential community leaders, to change what is considered acceptable.

\subsection{Rethinking government economic policy}

Commitments made at and since Beijing reflect an expectation that governments are responsible for implementing policies to improve the lives of women, especially poor women. However, the inconsistency between governments' ability to carry out these commitments, and the negative impact of neoliberal policies, has not been acknowledged or addressed (UNIFEM 2000: 10). The continued pursuit of growth-focused neoliberal policies has had a significant, and negative, impact on progress in all areas of gender equality, not just on women's economic empowerment. Cuts in public services, regressive taxation, privatisation, deregulation and austerity packages have all disproportionately disadvantaged women, especially the most marginalised, reducing their income and time and hence also their health, education and ability to participate in decision-making (Elson 1999).

Central to the incompatibility between current economic models and achieving gender justice has been continued failure to acknowledge the importance of the care economy (UNIFEM 2000: 10). So, for example, the real price of economic restructuring, paid mostly by women, is hidden by the transfer of costs from the public sector (where they are monetised) to the household (where they are not). The impact of women's care responsibilities has been huge, particularly for women with limited access to public services, reducing time for education, income-earning activities and participation in public and political life. Moreover, the lack of recognition and low status ascribed to care work further reduces women's and girls' status in society, and restricts their political voice and decision-making (Sepúlveda 2013). Alternative economic policies are needed that acknowledge the adverse impact of current ones on gender equality and recognise the importance of the care economy and women's role within it.

\section{Conclusion}

Real progress in achieving the aspirations laid down in the BPfA will require robust political will to make the difficult changes needed, alongside 
sufficient resources. These will come partly with stronger mechanisms to hold governments to account for implementing international and national commitments. But perhaps more importantly, they will come through the activism and advocacy of the women's rights movement. It is promising therefore that organisations and networks worldwide are marking the anniversary of the BPfA with renewed vigour and inspirational calls to action (see, for example, Asia Pacific Forum 2014).

But progress is never straightforward. The last two decades have witnessed an increasing backlash against hard-won advances, with alliances emerging and changing. Since the 1990s, the Vatican, Islamic fundamentalists and other states regressive on women's and girls' rights have threatened progressive agreements within the UN system. As advances in women's rights are achieved, opposition has also emerged from organisations purporting to promote the rights of men and boys. ${ }^{2}$ New forms

\section{Notes}

1 Gender and Development Network (http://gadnetwork.org), Gender Action for Peace and Security (http://gaps-uk.org), and the UK SRHR Network (www.bond.org.uk/the-uknetwork-for-sexual-and-reproductive-health-andrights).

\section{References}

ActionAid, IDS and Womankind Worldwide (2012) From the Ground Up: Women's Roles in Peacebuilding in Afghanistan, Liberia, Nepal, Pakistan and Sierra Leone, Brighton and London: ActionAid, IDS and Womankind Worldwide

Arutyunova, A. and Clark, C. (2013) Watering the Leaves, Starving the Roots: The Status of Financing for Women's Rights Organising and Gender Equality, Toronto: Association for Women's Rights in Development

Asia Pacific Forum (2014) Asia Pacific Beijing+20 Civil Society Forum Statement, www.isiswomen. org/downloads/CSO $\% 20$ Forum $\% 20$ Statement $\% 20$ FINAL $\% 2017 \% 20$ Nov $\% 2014$. pdf?utm_source $=$ emailcampaign $277 \&$ utm medium=phpList\&utm_content $=$ HTML\&utm campaign $=\% 5 \mathrm{Bwe} \% 21 \% 5 \mathrm{D}+$ The + Asia-Pacific + Review + on+Beijing $\% 2 B 20+$ Begins (accessed 26 May 2015)

AWID (2009) New Insights on Religious Fundamentalisms: Research Highlights, Toronto: Association of Women in Development

Development Initiatives (2014) Trends in Donor Spending on Gender in Development, Bristol: Development Initiatives of oppression through social media are also used against those who advocate for gender equality, and women's rights activists in every region face harassment and sexual violence (AWID 2009).

Over the last 20 years a plethora of international commitments has been put in place. The next decade must be one where action extends beyond a few priority areas towards comprehensively tackling the causes of gender inequality and so transforming the power relations between women and men, while remaining vigilant against the ever-present threat of backlash. As the post-2015 agenda is agreed and implemented, and action against commitments made at Beijing and in UNSCR 1325 are reviewed, international institutions, governments, the private sector and international non-governmental organisations (INGOs) have another chance to turn promises into real progress towards gender equality and women's rights.

2 See, for example, www.nytimes.com/2015/01/ 11/opinion/sunday/the-backlash-againstafrican-women.html?smid=tw-share\&_r=1 (accessed 30 January 2015) and https://j4mb. wordpress.com (accessed 24 January 2015).

Elson, D. (1999) 'Labor Markets as Gendered Institutions: Equality, Efficiency and Empowerment Issues', World Development 27.3: 611-27

Eyben, R. (2011) Supporting Pathways of Women's Empowerment: A Brief Guide for International Development Organisations, Pathways Policy Paper, Brighton: Pathways of Women's Empowerment GADN (Gender and Development Network), GAPS (Gender Action for Peace and Security) and UK SRHR Network (2015) Turning Promises into Progress, http://gadnetwork.org/turningpromises-into-progress (accessed 26 May 2015)

Global Campaign for Education (2011) From Rhetoric to Results: Closing the Global Education Gap for the World's Girls and Women, London: Global Campaign for Education

Groce, N. and Bakshi, P. (2011) 'Illiteracy among Adults with Disabilities in the Developing World: A Review of the Literature and a Call for Action', Fournal of Inclusive Education 15.10: 1153-68

Harper, G., Nowacka, K., Alder, H. and Ferrant, G. (2014) Measuring Women's Empowerment and Social Transformation in the Post-2015 Agenda, London and Paris: ODI and OECD Development Centre

Htun, M. and Weldon, L. (2012) 'The Civic Origins of Progressive Policy Change: Combating 
Violence against Women in Global Perspective, 1975-2005', American Political Science Review 106.3: 548-69

ILO (2009) Global Employment Trends for Women, Geneva: International Labour Organization

IPU (2014) Women in Politics 2014, New York NY: Inter-Parliamentary Union and UN Women

Kabeer, N. (2014) 'Gender Equality and Economic Growth: A View from Below', paper prepared for UN Women Expert Group Meeting 'Envisioning Women's Rights in the Post-2015 Context', New York, 3-5 November

Kabeer, N. (2005) 'Is Microfinance a "Magic Bullet" for Women's Empowerment: Analysis of Findings from South Asia', Economic and Political Weekly 40.44 and 40.45: 4709-18

Kidder, T.; Bright, D. and Green, C. (2014) Meaningful Action: Effective Approaches to Women's Economic Empowerment in Agriculture, Oxford: Oxfam

Klugman, J.; Hanmer, L.; Twigg, S.; Hasan, T.; McCleary-Sills, J. and Santamaria, J. (2014) Voice and Agency: Empowering Women and Girls for Shared Prosperity, World Bank Group, https://openknowledge.worldbank.org/ handle/10986/19036 (accessed 29 May 2015)

Ministry of Communication, Bolivia (2012) 'Law No. 243 Policy Against Harassment and Violence Against Women', www.comunicacion.gob. bo/?q=20130725/ley-n \%C2\%BA243-contrael-acoso-y-violencia-politica-hacia-las-mujeres (accessed 26 May 2015)

Sepúlveda, C.M. (2013) 'Unpaid Care Work, Poverty and Women's Human Rights: Challenges and Opportunities for the Post-2015 Agenda', observer paper submitted for the Expert Group Meeting on Structural and Policy Constraints in Achieving the MDGs for Women and Girls, EGM/MDG/OP.1, UN Women in collaboration with ECLAC, Mexico City, 21-24 October
Smee, S. and Woodroffe, J. (2013) Achieving Gender Equality and Women's Empowerment in the Post-2015 Framework, London: Gender and Development Network

UK SRHR Network (Network on Sexual and Reproductive Health and Rights), Gender and Development Network (GADN), Action for Global Health and Stop Aids (2014) A Manifesto for Motherhood: Briefing for MPs and Parliamentary Candidates, London: UK SRHR Network UNIFEM (2000) Progress of the World's Women 2000, New York NY: UNIFEM

United Nations (2014a) Millennium Development Goals Report 2014, New York NY: United Nations United Nations (2014b) The Road to Dignity by 2030: Ending Poverty, Transforming All Lives and Protecting the Planet, Synthesis Report of the Secretary-General on the Post-2015 Agenda, New York NY: UN

United Nations (2010) Ten Year Impact Study on Implementation of UN Security Council Resolution 1325 (2000) on Women, Peace and Security in Peacekeeping, Department of Peacekeeping Operations, Department of Field Support, New York NY: UN

UN Women (2015) Progress of the World's Women 2015-2016: Transforming Economies, Realizing Rights, New York NY: UN Women

UN Women (2012) Women's Participation in Peace Negotiations: Connections between Presence and Influence, New York NY: UN Women

Wallace, T. and Porter, F. (eds) (2013) Aid, NGOs and the Realities of Women's Lives: A Perfect Storm, Rugby: Practical Action Publishing

WHO (2013) Global and Regional Estimates of Violence against Women, Geneva: World Health Organization

Women Deliver (2013) Invest in Equality, New York NY: Women Deliver 